\title{
Dynamics of export market entry and exit
}

\author{
Pekka Ilmakunnas*
}

Helsinki School of Economics and HECER

Satu Nurmi**

Statistics Finland

August 29, 2007

\begin{abstract}
We examine the process of internationalisation of firms, contributing to the knowledge on the factors behind a successful entry and operation in the export markets using duration analysis. Rich longitudinal micro-level data on Finnish manufacturing plants allow an in-depth analysis of the life cycle of exporting plants over a time span of up to 25 years. In the first part of the analysis, we focus on the factors that explain the duration of time until entering plants start to export. The second part of the study concentrates on the duration of time until exit from the export markets. Our special focus is on the effects of foreign ownership, human capital and industry spillovers on export market entry and exit.
\end{abstract}

Keywords: export dynamics, foreign ownership, human capital, duration analysis JEL-code: C41, F14, F23, L25

* Pekka Ilmakunnas, Helsinki School of Economics, PO Box 1210, FI-00101 Helsinki, Finland, e-mail pekka.ilmakunnas@hse.fi

** Satu Nurmi, Statistics Finland, Työpajankatu 13, FIN-00022 Statistics Finland, Finland, Email: satu.nurmi@stat.fi 


\section{Introduction}

Recent decades of rapid globalisation and technological change have increased the need for a deeper understanding of the process of internationalisation. Export markets offer firms with growth potential an important channel for expansion. In the face of increasing competition, further pressure is put to firm productivity and efficient use of resources. According to recent heterogeneous firm trade models (e.g., Bernard et al., 2003; Bernard, Redding, and Schott, 2004; Melitz, 2003), the exposure to trade may enhance the growth opportunities of some firms, while simultaneously contributing to the downsizing of other firms in the same industry. Differences in the firms' reactions may be explained by the differences in the underlying characteristics of the firms.

Melitz (2003) develops a dynamic industry model with heterogeneous firms and monopolistic competition. The model includes sunk costs related both to entering the industry and to entering the export market. Through higher profit opportunities and increased entry, exposure to trade increases the efficiency (or productivity) thresholds required for exporting and surviving, thus forcing the least efficient firms to exit. The export market selection effect and the domestic market selection effect both lead to the reallocation of market shares towards the more efficient firms increasing the average productivity in the industry.

Following increased availability of firm- and plant-level data sets, there has been an upsurge in empirical analyses of exporting that partly predates the theoretical work. ${ }^{\text {T }}$ The key issue has been the connection of exporting and firm performance and related to this, the determinants of entry and exit in export markets. The motivation for most of the studies has been to examine whether high-productivity firms are selected to exporting or whether there is learning-byexporting, i.e. exporting leads to higher productivity ${ }^{2}$. They have found that exporters tend to be larger, more productive, and more capital- and technology-intensive. Furthermore, they pay higher wages and supply products of higher quality.

However, the direction of causality between exporting and good performance is less clear. There is evidence that good plants have a higher probability of becoming exporters. Most of

\footnotetext{
${ }^{1}$ For example, Wagner (2007) summarizes evidence from 45 different studies on exporting and productivity.

${ }^{2}$ See e.g. Greenaway and Kneller (2007), Lopez (2005), Tybout (2003), and Wagner (2007), for surveys of the issues.
} 
the evidence supports the selectivity view of exports rather than learning-by-exporting, as exporting shows little evidence of boosting firm productivity. In some studies, however, support is found for the learning effects. B Bernard and Jensen (1999) also find that exporting has positive effects on the probability of survival and employment growth. The work on export exit by Girma et al. (2003), on the other hand, shows that there may be short-run negative productivity effects, but longer-run negative effects on output and employment.

Importantly, there is much persistence in exporting. Many studies have found that sunk entry costs and prior export experience are important in explaining plant's exporting status (e.g., Das et al., 2007; Roberts \& Tybout, 1997). Being an exporter in the previous period has typically a statistically and economically highly significant effect on the probability of currently being an exporter.

The pre-export development of firms has not received as much attention as export entry. Lopez (2005) reviews evidence of conscious self-selection to exporting, which can take place through investments in new technology or R\&D. In Alvarez and Lopez (2005) this is tested by explaining the probability of a plant to start exporting (given that it did not export in the previous year) by lagged investments. In another kind of analysis of the pre-export phase Fafchamps et al. (2007) test two alternative models of learning to export, productivity learning and market learning, using duration analysis. They find evidence on market learning, whereby firms learn to design products that appeal to foreign consumers.

The purpose of this paper is to contribute to the knowledge on the factors behind a successful entry and operation in the export markets by analysing how long it takes for new plants to start exporting and for how long exporting lasts once it has started. Our approach contrasts with the earlier studies on export entry and exit, which have used binary dependent variable models for exporting status, often with a lagged dependent variable included to account for persistence. Rich longitudinal micro-level data on Finnish firms and plants allow an in-depth analysis of the life cycle of exporting plants over a time span of up to 25 years. The Finnish economy has undergone dramatic changes during this period, including a period of deep recession at the

\footnotetext{
${ }^{3}$ Greenaway \& Kneller (2004) find that industry differences are important in determining whether learning by exporting plays a central role in productivity development. Some studies have also found export learning in young plants or during the first years of export activity (Lopez, 2005). Girma et al. (2004) find, using matching techniques, support both for the selectivity effects and for a further boost to productivity from exports.
} 
beginning of 1990s and profound plant- and sector-level structural changes in the business sector. Furthermore, the competitive environment has changed considerably due to the liberalisation of financial markets and international trade, as well as the EU membership in 1995. In this changing business environment, we are able to shed light on questions concerning the background characteristics of those plants that export, the timing of start-up in export markets and the duration of exporting. Unique linked employer-employee data allow us to include information on the employees of each plant in the analysis to account for human capital. Furthermore, we are able to study the effects of foreign ownership and the spillover effects from other exporting plants.

We will proceed as follows. In Section 2 of the paper we explain our econometric approach and in Section 3 the data set that we are using. Section 4 presents results on export market entry and exit. Section 5 concludes the paper.

\section{The econometric approach}

Most of the studies that analyse export market participation model this as a discrete choice. A firm exports in period $t$ if the expected benefits from exporting exceed the sunk entry cost, which are incurred if the firm does not export in $t-1$. Similarly, the firm does not export in period $t$ if the expected benefits are too low, taking into account exit cost which is incurred if the firm exports in $t-1$. In this kind of studies the interest is in the sequence of 1 's (exports) and 0's (does not export) for the firms in the data set. Since structural modelling of the dynamic decision problem is fairly complicated, the studies (except for Das et al., 2007) use a reduced form approach. They either estimate the participation using probit with random effects to account for firm-specific time-invariant differences in the propensity to export (e.g. Roberts and Tybout, 1997), or model the participation decision jointly with a (continuous) productivity equation (e.g. Clerides, Lach, and Tybout, 1998). Since there is state dependence, i.e. export participation depends on past export status, these studies pay attention to the initial condition by also modeling the probability of exporting in the initial year of the panel. A simpler approach, taken by Bernard and Jensen $(1999,2004)$ is to use a linear probability model with differencing to remove individual effects and GMM estimation to account for the lagged dependent variable. 
The export market entry and exit studies essentially take a stock sample of existing plants or firms and study their subsequent entry and exit behaviour. We take a different approach: we use a flow sample of plants that enter our data set (as explained below, entry is defined as passing a lower size limit) and then model the duration until they start to export for the first time. Then, using data on plants that start exporting, we model the duration of export activity until exit from the export market. The only other study that we are aware of which uses duration analysis for analysing exports is Fafchamps et al. (2007). They have data on separate products and they study the duration until start of exporting for new products, given the possible previous export experience for other products. They do not model the duration from the birth of the firm until first export activity, but simply regress the share of production that goes to exports on firm age.

Following the earlier literature (Roberts and Tybout, 1997, Clerides et al., 1998), the plant chooses a sequence of export market participation decisions. In period $t$ the exporting profits are

$\pi_{t} \mathbf{1}\left(X_{t}>0\right)-F_{E N} 1\left(X_{t}>0\right) \mathbf{1}\left(X_{t-1}=0\right)-F_{E X} 1\left(X_{t}=0\right) 1\left(X_{t-1}>0\right)$

where $\pi_{t}$ measures the difference in profits when the plant exports compared to the situation that it does not export, $F_{E N}$ and $F_{E X}$ are export entry and exit costs, respectively, $X_{t}$ is exports, and 1(.) is an indicator function. To simplify things, we assume that past export history does not matter beyond period $t-1$. Following from Bellman's equation (Roberts and Tybout, 1997) the plant will export in period $t$ if

$\pi_{t}+\delta\left[E_{t}\left(V_{t+1} \mid X_{t}>0\right)-E_{t}\left(V_{t+1} \mid X_{t}=0\right)\right] \geq F_{E N}-\left(F_{E N}+F_{E X}\right) \mathbf{1}\left(X_{t-1}>0\right)$

where $V_{t+1}$ is the maximized expected present value of future payoffs and $\delta$ is the discount rate. Our emphasis is in the first decision to start exporting and hence the plant has no export history, i.e. $X_{t-1}=0$. In the first period $t^{*}$ when export is observed it therefore has to hold that $\pi_{t^{*}}+\delta\left[E_{t^{*}}\left(V_{t^{*}+1} \mid X_{t^{*}}>0\right)-E_{t^{*}}\left(V_{t^{*}+1} \mid X_{t^{*}}=0\right)\right] \geq F_{E N}$

In the extreme case, of course, a plant enters and starts to export in the same period. The purpose of our analysis is to model $t^{*}$, the duration until exporting starts.

\footnotetext{
${ }^{4}$ For other examples and variants of the analysis, see van Biesenbroeck (2005) and Campa (2004), among others.
} 
To illustrate the process leading to exports, we can make specific assumptions about revenues and costs. At time $t=0$ the plant enters, after which there is in each time period learning which leads to lowering of production costs. If the firm enters the export market, it sells $D_{t}$ domestically and exports $X_{t}$, and receives corresponding revenues $R^{D}\left(D_{t}, z_{t}^{D}, t\right)$ and $R^{X}\left(X_{t}, z_{t}^{D}, t\right)$. The $z$ 's are demand shift factors, e.g. business cycle variables, that affect the revenues. Time $t$ is included in export revenues to describe "demand learning" through which revenues increase over time. For example, through learning the plant may get a better price for its product in the export market. The cost function is $C\left(X_{t}+D_{t}, z_{t}{ }^{C}, t\right)$, where $z^{C}$ is a cost shift factor, e.g. shocks to input prices. Time $t$ is included in the cost function to account for "production learning" through which costs decrease over time. For example, the costs can decrease over time according to $C(., t)=c().\left(1+\delta e^{-x}\right)$. This implies that the firm enters with costs $c().(1+\delta)$ and over time the costs fall to $c($.).

The plant's profits with exports are

$\pi_{t}^{X}=R^{X}\left(X_{t}, z_{t}^{X}, t\right)+R^{D}\left(D_{t}, z_{t}^{D}\right)-C\left(X_{t}+D_{t}, z_{t}^{C}, t\right)$

and without exports the profits are

$\pi_{t}^{D}=R^{D}\left(D_{t}^{\prime}, z_{t}^{D}\right)-C\left(D_{t}^{\prime}, z_{t}^{C}, t\right)$

Where $D^{\prime}{ }_{t}$ denotes domestic sales when there is no exporting. It follows that the profit difference between exporting and not exporting is

$$
\pi_{t}=R^{X}\left(X_{t}, z_{t}^{X}, t\right)+R^{D}\left(D_{t}, z_{t}^{D}\right)-R^{D}\left(D_{t}^{\prime}, z_{t}^{D}\right)+C\left(D_{t}^{\prime}, z_{t}^{C}, t\right)-C\left(X_{t}+D_{t}, z_{t}^{C}, t\right)
$$

The attractiveness of both exporting and producing to the home market, compared to only domestic sales depends on the domestic and export revenues, economies of scale in production, and the state of the learning process. The plant can start with a low value of (6) (and the present value of future profits $V$ ), but over time exporting becomes more profitable through the learning effects and/or there are favourable shocks to demand or costs. ${ }^{\mathrm{B}}$ The plant will start exporting at time $t^{*}$ when condition (3) holds for the first time. It is also possible to influence the timing of entry to export market (i.e. to engage in conscious self-selection to exporting), for example by investing in human capital of the employees, which can affect the rate of production or demand learning.

\footnotetext{
${ }^{5}$ Positive domestic demand shocks may make exports relatively less profitable.
} 
Once the plant has entered the export market, it will exit in period $t^{* *}$ if the condition

$$
\pi_{t^{* *}}+\delta\left[E_{t^{* *}}\left(V_{t^{* *+1}} \mid X_{t^{* *}}>0\right)-E_{t^{* *}}\left(V_{t^{* *+1}} \mid X_{t^{* *}}=0\right)\right]<-F_{E X}
$$

holds, i.e. if the losses from staying in the export market exceed the exit cost. The analysis of duration of export activity starts from the period $t^{*}$ when the plant enters the export market ((3) holds for the first time). The firms can then either continue exporting or exit at period $t^{* *}$ when (7) holds for the first time after $t^{*}$. The exit can take the form of either exit only from exports but continued activity in the home market, or complete shutdown of activities. In the light of the assumed forms of the profits, the exit may result from unfavourable shocks to export revenues or costs, especially when combined with possible slowing down of the rate of learning.

In the econometric analysis we approximate the equations (3) and (7) by linear functions of the explanatory variables. A discrete-time model of export duration is preferred because the annual nature of the data causes interval-censoring. A flexible, non-parametric specification of the baseline hazard is used in the estimation. This means including duration dummies for each interval in the estimation. We use a discrete-time proportional hazard duration model, where the discrete interval hazard rate follows a complementary log-log distribution (e.g. Prentice and Gloeckler, 1978):

$h_{i t}=\operatorname{prob}\left(T_{i}<t+1 \mid T_{i} \geq t\right)=1-\exp \left[-\exp \left(\beta^{\prime} x_{i t}+\gamma_{t}\right)\right]$

where $\gamma_{t}$ is the baseline hazard. $T_{i}$ refers here to $t^{*}$ in case of duration until exporting and to $t^{* *}$ in case of duration until exit. This specification also allows us to control for plant-level unobserved heterogeneity. To account for unobserved heterogeneity, we include normally distributed random effects in the model

$h_{i t}=1-\exp \left[-\exp \left(\beta^{\prime} x_{i t}+\gamma_{t}+v_{i}\right)\right]$

where $v_{i} \sim N\left(0, \sigma_{v}{ }^{2}\right)$ are the unobserved individual effects.

\section{The data}

Our data sources are from Statistics Finland. The primary data source is a panel data on manufacturing plants based on the Longitudinal Data of Plants in Manufacturing (LDPM), which is available for the period 1974-2005. The LDPM data includes information, for example, on plant-level employment, working hours, value added, production, exports, 
foreign ownership, investments, capital stock and wages. In addition, there is information on industry and region of the plant and the number of plants in the firm. The age information of the plant can be supplemented from the Business Register. There is a break in the LDPM data set between the years 1994-1995, when size threshold for plants increased from 5 to 20 persons (actually, plants belonging to firms with at least 20 employees). Our estimation sample consists of manufacturing plants that reach the 20 employees threshold for the first time during the period 1980-2005. In fact, this group may include both new and continuing establishments that have already been in operation with less than 20 employees. As a result, it is important to control for the age of these plants. In the duration analysis we pool multiple cohorts of new plants over the period 1980-2005.

The Foreign Affiliates Statistics (FATS) 1994-2005 data include information on the ultimate beneficiary owner (UBO) of the plant, including the share of foreign ownership. The Group Register 1995-2005 includes further information on the links between multinational group parents and their daughters. However, there are some problems in the comparability and quality of these data sets. The Finnish Longitudinal Employer-Employee Data (FLEED) 19882004 include background information on employees of each plant, which makes it possible to construct variables that describe average characteristics of employees, including education, age, work experience, share of women, etc.

In the first part of the analysis, we focus on the factors that explain the duration of time until these plants start to export. We use 26 cohorts of plants from the years 1980-2005. When the human capital variables are included, the data period is shorter, 1988-2004. An entry event is recorded when the plant has positive exports for the first time after "birth" (as defined by the size threshold). If the plant does not start to export, it becomes censored at the end of the spell. To take into account missing observations, we allow for one-year absence from the data. A longer absence is considered as "death". We concentrate on the first spells and do not include a plant again once it has exited the export market for the first time.

The second part of the study concentrates on what happens to the exporters. We follow plants that both start exporting and have at least 20 employees for the first time after 1974, using the 25 cohorts 1980-2005 and controlling for plant age. When the human capital variables are included, the data period is 1988-2004. An exit event is recorded when the plant no longer has 
positive exports or has less than 20 employees. All observations for the year 2005 are censored, since we do not know what happens to the plants after that year. Again, we allow for one year absence from the export market, but a longer absence is considered as export market exit.

We have several explanatory variables for export entry and exit. To some extent the variables are similar to those used in binary choice export models, but we can exploit the rich employeremployee data set to form variables that describe human capital in the plants.

Plant size accounts for scale effects. For example, Wagner (1995) has found that the impact of firm size on exports is positive but decreasing. We measure plant size by the logarithm of the number of employees. Plant age is an important control variable. Unfortunately, reliable continuous plant age information is only available in the LDPM data from 1975 onwards, whereas for older plants it has to be supplemented from the Business Register, where the quality is not comparable. As an alternative we are able to divide plants into age groups based on ordered plant coding, which is our preferred measure for plant age.

Most of the studies on exporting emphasise the connection to productivity. Since we are concerned with the phase preceding export market entry, our productivity effects are selectivity effects. In the exit models we do not have non-exporters, so there we do not distinguish between higher productivity already before the entry to exports and higher productivity gained during exporting. We measure productivity by the logarithm of value added per hours worked.

Capital intensive plants are likely to have scale economies, which encourage entry to export markets. They may also be less inclined to exit. We measure capital intensity by the logarithm of capital-labor ratio. Similarly, higher ratio of investments per output may indicate a higher ability to export.

Price-cost margin measures current profitability. Plants with higher profitability without exports are more likely to reach condition (3) early on and exporting plants with high profitability are less likely to face the exit condition (7). 
The literature on foreign direct investment emphasises the advantages of multinationals, which may be based on firm-specific assets or joint inputs that can be flexibly used within the firm in different locations, scale effects, or better access to technology. This may be reflected also in the export behaviour of foreign-owned plants. We therefore include an indicator for foreign ownership, which is based on the share of foreign ownership exceeding $50 \%$ (direct owner before 1995 and ultimate beneficiary owner (UBO) from 1995 onwards). We expect foreign ownership to shorten the duration until export entry and to decrease the risk of exit from the export market.

It is likely that plants that belong to multi-unit firms enter export markets earlier, but may be more likely to exit early if the firm can switch export activities from one plant to another. We therefore include an indicator for plants that are part of a multiplant firm.

The effects of human capital on exporting behaviour have received less attention due to lack of suitable data. For example, in many studies of exports wages are used for measuring the "quality" of the labour input. Roper et al. (2006) have found that larger, externally-owned plants with higher skill levels have the highest export propensities. On the other hand, there is also evidence on the important role of innovative capabilities in export behaviour (Basile, 2001; Roper and Love, 2002). We measure workforce skills and innovative capabilities by two variables, the share of highly educated employees (those with a university degree) and the share of employees with a technical education. As an alternative measure, we use average education years, which is obtained by converting degrees to years with standard graduation times.

We have two additional variables that measure labour quality, average age and average tenure of employees. Plants that have an old work force may be less innovative and can have old equipment, since typically the age of plant and age of employees are correlated. We therefore expect age to be negatively correlated with export entry and positively with exit. On the other hand, tenure can to some extent compensate for the age effects, if there are plant-specific skills. However, very long tenure can have same kind of effects as age. In addition, we control the share of female employees. 
Spillovers from other firms have been investigated in some studies. We include as a spillover measure the employment share of other plants in the industry which are engaged in export activity. The other exporters likely act as examples for new plants that have aspirations to start exporting. On the other hand, the spillover effect on the survival as an exporter is most likely smaller or non-existent, since a mere example of the others may not help in adverse times.

To control for general cyclical effects we include growth of real GDP as an explanatory variable. All of the explanatory variables described above are time-varying covariates in the duration models (8) and (9). In addition, we have indicators for industry (23 2-digit SIC 1995 industries) and region (20 NUTS3 regions).

Table 1 gives more precise variable definitions. Descriptive statistics for all manufacturing plants having at least 20 employees are presented in Table 2. A simple comparison of mean characteristics of exporting plants and non-exporters shows that exporters are on average larger, older, more productive, more capital-intensive and more likely to be foreign-owned. In terms of the work force, exporters have somewhat more experienced and better educated personnel than those plants that do not export.

Table 1. Variable definitions

\begin{tabular}{|c|c|}
\hline Variable & Description \\
\hline Plant size & Log of employment \\
\hline Plant age & Plant age (qualitative problems for older plants) \\
\hline Plant age groups & Age groups based on quartiles of ordered plant codes \\
\hline Labour productivity & Log of (value added per hours worked) \\
\hline Capital intensity & Log of (capital-labour ratio) \\
\hline Investment rate & Gross investments per gross output \\
\hline Price-cost margin & (Value added - wages - materials) / Value added \\
\hline Multi-unit & Plant belongs to a multi-site firm $=1$, else $=0$ \\
\hline Foreign ownership & $\begin{array}{l}\text { Plant belongs to a firm with a share of foreign ownership } \\
\text { exceeding } 50 \%=1 \text {, else }=0\end{array}$ \\
\hline Share of other exporters & Employment share of other exporters in the industry \\
\hline Share of women & Share of women in the plant \\
\hline Mean seniority (months) & $\begin{array}{l}\text { Average firm-related work experience in the plant } \\
\text { (months) }\end{array}$ \\
\hline Mean age of employees & Average age of employees in the plant \\
\hline Share of technically educated & Share of technically educated employees in the plant \\
\hline Share of highly educated & $\begin{array}{l}\text { Share of highly educated (having a degree from tertiary } \\
\text { education) employees in the plant }\end{array}$ \\
\hline Mean schooling years & Average years of schooling in the plant \\
\hline
\end{tabular}

Note: All variables may be time-varying. 
Table 2. Descriptive statistics 1988-2004

\begin{tabular}{lrrr}
\hline Mean characteristics & $\begin{array}{r}\text { Non- } \\
\text { exporters }\end{array}$ & Exporters & All plants \\
1988-2004 & 67.43 & 139.71 & 116.36 \\
\hline Plant size (persons) & 20.00 & 23.73 & 22.53 \\
Plant age & 25.06 & 31.58 & 29.47 \\
Labour productivity & 27.03 & 36.20 & 33.29 \\
Capital intensity & 0.23 & 0.06 & 0.11 \\
Investment rate & -2.96 & 0.08 & -0.90 \\
Price-cost margin & 0.33 & 0.35 & 0.34 \\
Multi-unit & 0.05 & 0.12 & 0.09 \\
Foreign ownership & 0.35 & 0.31 & 0.32 \\
Share of women & 109.46 & 122.18 & 118.16 \\
Mean seniority (months) & 38.90 & 39.39 & 39.23 \\
Mean age of employees & 0.42 & 0.46 & 0.45 \\
Share of technically educated & 0.17 & 0.21 & 0.20 \\
Share of highly educated & 11.49 & 11.72 & 11.65 \\
Mean schooling years & 16253 & 34051 & 50304 \\
Number of observations & & & \\
\hline
\end{tabular}

\section{Estimation results}

\subsection{Export entry}

Figure 1 shows Kaplan-Meier survival estimates for export market entry, where survival is defined as not entering the export market. Almost half of the plants start to export in the same year as they appear in our data. This corresponds to the overall share of exporters in plants with more than 20 employees. In fact, in the previous year these plants may have already been exporters below the size threshold. In the estimations this can at least partly be controlled by taking into account plant age. In addition, we are able to do some other sensitivity checks. Otherwise, the decline in the survival function is quite modest and stabilises for longer durations, where the number of observations is fewer. When the survival functions are graphed separately according to foreign ownership (Figure 2), it becomes evident that foreignowned plants are more likely to enter the export market. However, further analysis is needed in order to control for other factors affecting export entry.

The estimation results for the export entry models are reported in Table 3. Plant size is consistently positively related to the probability of starting to export. According to model 3, a $10 \%$ increase in size increases the chances of export market entry by around $4 \%$. In the first column we include plant age as a continuous variable, whereas in the other models age is accounted for by the more reliable age group dummy variables, higher group number 
indicating a later cohort, i.e. younger plants. Age seems to decrease the probability of entering, except in the last three columns, where employee characteristics are included. This is most likely caused by the fact that plant age is correlated with average employee age and tenure. More productive plants are more likely to enter the export market, which supports the selectivity view of export entry. Capital intensity is positively related to export entry, but this effect is no longer significant when the employee characteristics are included. These findings correspond to the earlier literature on export entry.

Among the other plant characteristics only foreign ownership obtains a significant coefficient. 6 The indicator of foreign owned plants has a positive coefficient, but its interaction with plant size a negative one. Since plant size has separately a positive impact, this means that foreign ownership increases the probability of starting to export especially for the smaller plants. This can more clearly be seen in Figure 3, where predicted survival functions are plotted for combinations of foreign ownership and two plant size groups (up to 50 employees, over 50 employees).

Since the effect of foreign ownership may also depend on other plant characteristics, we also tested its interactions with plant age, labour productivity and education. According to the results (not shown), the interactions with plant age and labour productivity were statistically insignificant. By contrast, the interactions with the variables describing the educational level of the work force were negative indicating that foreign ownership increases the likelihood of export entry more for plants with less highly-educated employees.

There is indication of a positive spillover effect, as the share of other exporters in the same industry obtains a positive coefficient. This finding is robust to measuring the share of other exporters by output or number of plants instead of employment. We have also experimented with the share of other exporters in the same region (NUTS 4), which turns out to have a statistically significant, positive effect on export entry as well. However, the example of other exporters in the same field of production seems to be more important than regional influences.

\footnotetext{
${ }^{6}$ An indicator for belonging to a multinational group (available only from 1997 onwards) does not yield any significance in export entry and exit models.
} 
Among the employee characteristics variables there is evidence that employee tenure has a negative and education a positive impact on export market entry. The effect of education is very similar regardless of the way we measure education, i.e. by mean schooling years or the share of highly educated.

The duration dummies show a non-monotonic, negative pattern of duration dependence, i.e. the hazard of entering the export market declines over time. There are statistically significant differences in the probability of export entry between different industries and regions. Using more detailed industry (3-digit SIC 1995) and region dummies (NUTS 4) in the estimations yields very similar results.

To take into account the fact that our models may exclude some important explanatory variables describing plant-level heterogeneity, like unobserved motives for export entry, we also estimate the models with random effects (columns 4 and 7 of Table 3). This yields results that do not differ much from the corresponding estimates without unobserved heterogeneity accounted for.

Table 3. Estimation results for export market entry

\begin{tabular}{|c|c|c|c|c|c|c|c|}
\hline ENTRY & (1) & $(2)$ & (3) & (4) & (5) & (6) & $(7)$ \\
\hline \multirow[t]{2}{*}{ Plant size } & 0.391 & 0.382 & 0.414 & 0.492 & 0.403 & 0.404 & 0.474 \\
\hline & $(0.038)^{* * *}$ & $(0.039)^{* * *}$ & $(0.040)^{* * *}$ & $(0.049)^{* * *}$ & $(0.063)^{* * *}$ & $(0.063)^{* * *}$ & $(0.076)^{* * *}$ \\
\hline \multirow[t]{2}{*}{ Plant age } & -0.524 & & & & & & \\
\hline & $(0.039)^{* * *}$ & & & & & & \\
\hline \multirow[t]{2}{*}{ Plant age group 2} & & 0.591 & 0.602 & 0.690 & 1.093 & 1.114 & 1.247 \\
\hline & & $(0.201)^{* * *}$ & $(0.202)^{* * *}$ & $(0.220)^{* * *}$ & $(0.345)^{* * *}$ & $(0.347)^{* * *}$ & $(0.382)^{* * *}$ \\
\hline \multirow[t]{2}{*}{ Plant age group 3} & & 0.619 & 0.625 & 0.708 & 1.005 & 1.024 & 1.136 \\
\hline & & $(0.186)^{* * *}$ & $(0.186)^{* * *}$ & $(0.203)^{* * *}$ & $(0.305)^{* * *}$ & $(0.306) * * *$ & $(0.329)^{* * *}$ \\
\hline \multirow[t]{2}{*}{ Plant age group 4} & & 0.649 & 0.650 & 0.742 & 0.792 & 0.803 & 0.890 \\
\hline & & $(0.183)^{* * *}$ & $(0.183)^{* * *}$ & $(0.198)^{* * *}$ & $(0.293)^{* * *}$ & $(0.294)^{* * *}$ & $(0.313)^{* * *}$ \\
\hline \multirow{2}{*}{$\begin{array}{l}\text { Plant age group } 5 \\
\text { (the youngest) }\end{array}$} & & 0.720 & 0.716 & 0.841 & 0.877 & 0.893 & 1.017 \\
\hline & & $(0.185)^{* * *}$ & $(0.185)^{* * *}$ & $(0.203)^{* * *}$ & $(0.286)^{* * *}$ & $(0.287)^{* * *}$ & $(0.307)^{* * *}$ \\
\hline \multirow[t]{2}{*}{ Labour productivity } & 0.172 & 0.162 & 0.164 & 0.188 & 0.172 & 0.156 & 0.184 \\
\hline & $(0.040) * * *$ & $(0.039)^{* * *}$ & $(0.039)^{* * *}$ & $(0.043)^{* * *}$ & $(0.065)^{* * *}$ & $(0.067)^{* *}$ & $(0.082)^{* *}$ \\
\hline \multirow[t]{2}{*}{ Capital intensity } & 0.049 & 0.058 & 0.058 & 0.071 & 0.031 & 0.032 & 0.040 \\
\hline & $(0.016)^{* * *}$ & $(0.016)^{* * *}$ & $(0.016)^{* * *}$ & $(0.018)^{* * *}$ & $(0.024)$ & $(0.024)$ & $(0.028)$ \\
\hline \multirow[t]{2}{*}{ Investment rate } & -0.004 & -0.005 & -0.005 & -0.005 & -0.039 & -0.049 & -0.097 \\
\hline & $(0.003)$ & $(0.003)$ & $(0.003)$ & $(0.014)$ & $(0.162)$ & $(0.163)$ & $(0.205)$ \\
\hline \multirow[t]{2}{*}{ Price-cost margin } & 0.010 & 0.008 & 0.009 & 0.013 & 0.037 & 0.061 & 0.093 \\
\hline & $(0.017)$ & $(0.016)$ & $(0.017)$ & $(0.037)$ & $(0.084)$ & $(0.102)$ & $(0.176)$ \\
\hline \multirow[t]{2}{*}{ Multi-unit } & -0.081 & -0.071 & -0.080 & -0.115 & 0.024 & 0.025 & 0.002 \\
\hline & $(0.064)$ & $(0.065)$ & $(0.065)$ & $(0.074)$ & $(0.099)$ & $(0.100)$ & $(0.111)$ \\
\hline \multirow[t]{2}{*}{ Foreign ownership } & 0.087 & 0.086 & 1.256 & 1.427 & 1.479 & 1.418 & 1.639 \\
\hline & $(0.114)$ & $(0.114)$ & $(0.495)^{* *}$ & $(0.576)^{* *}$ & $(0.637)^{* *}$ & $(0.643)^{* *}$ & $(0.731)^{* *}$ \\
\hline $\begin{array}{l}\text { Foreign ownership*plant } \\
\text { size }\end{array}$ & & & -0.286 & -0.321 & -0.336 & -0.325 & -0.378 \\
\hline
\end{tabular}




\begin{tabular}{|c|c|c|c|c|c|c|c|}
\hline & & & $(0.120)^{* *}$ & $(0.141)^{* *}$ & $(0.159)^{* *}$ & $(0.160)^{* *}$ & $(0.181)^{* *}$ \\
\hline Share of other exporters & $\begin{array}{l}2.779 \\
(0.215)^{* * *}\end{array}$ & $\begin{array}{l}2.758 \\
(0.216)^{* * *}\end{array}$ & $\begin{array}{l}2.770 \\
(0.216)^{* * *}\end{array}$ & $\begin{array}{l}3.114 \\
(0.241)^{* * *}\end{array}$ & $\begin{array}{l}2.970 \\
(0.333)^{* * *}\end{array}$ & $\begin{array}{l}2.942 \\
(0.333) * * *\end{array}$ & $\begin{array}{l}3.364 \\
(0.365)^{* * *}\end{array}$ \\
\hline Mean age of employees & & & & & $\begin{array}{l}0.005 \\
(0.009)\end{array}$ & $\begin{array}{l}0.001 \\
(0.009)\end{array}$ & $\begin{array}{l}0.002 \\
(0.011)\end{array}$ \\
\hline Mean seniority & & & & & $\begin{array}{l}-0.002 \\
(0.001)^{* *}\end{array}$ & $\begin{array}{l}-0.002 \\
(0.001)^{* *}\end{array}$ & $\begin{array}{l}-0.002 \\
(0.001)^{* *}\end{array}$ \\
\hline $\begin{array}{l}\text { Share of technically } \\
\text { educated }\end{array}$ & & & & & 0.095 & 0.329 & 0.331 \\
\hline Mean schooling years & & & & & $\begin{array}{l}(0.248) \\
0.161 \\
(0.035)^{* * *}\end{array}$ & $(0.235)$ & $(0.268)$ \\
\hline Share of highly educated & & & & & & $\begin{array}{l}1.114 \\
(0.191)^{* * *}\end{array}$ & $\begin{array}{l}1.321 \\
(0.230)^{* * *}\end{array}$ \\
\hline Share of women & & & & & $\begin{array}{l}-0.163 \\
(0.223)\end{array}$ & $\begin{array}{l}-0.153 \\
(0.223)\end{array}$ & $\begin{array}{l}-0.135 \\
(0.261)\end{array}$ \\
\hline Growth in real GDP & $\begin{array}{l}-0.363 \\
(1.164)\end{array}$ & $\begin{array}{l}-0.441 \\
(1.159)\end{array}$ & $\begin{array}{l}-0.460 \\
(1.158)\end{array}$ & $\begin{array}{l}-0.356 \\
(1.220)\end{array}$ & $\begin{array}{l}0.450 \\
(1.563)\end{array}$ & $\begin{array}{l}0.472 \\
(1.563)\end{array}$ & $\begin{array}{l}0.659 \\
(1.693)\end{array}$ \\
\hline Constant & $\begin{array}{l}-3.945 \\
(0.248)^{* * *}\end{array}$ & $\begin{array}{l}-4.962 \\
(0.298)^{* * *}\end{array}$ & $\begin{array}{l}-5.090 \\
(0.304)^{* * *}\end{array}$ & $\begin{array}{l}-5.842 \\
(0.364)^{* * *}\end{array}$ & $\begin{array}{l}-7.329 \\
(0.687)^{* * *}\end{array}$ & $\begin{array}{l}-5.583 \\
(0.584) * * *\end{array}$ & $\begin{array}{l}-6.424 \\
(0.698) * * *\end{array}$ \\
\hline Random effects & NO & $\mathrm{NO}$ & $\mathrm{NO}$ & YES & NO & NO & YES \\
\hline $\begin{array}{l}\text { Observations } \\
\text { Number of id }\end{array}$ & 8259 & 8258 & 8258 & $\begin{array}{l}8308 \\
3364\end{array}$ & 3151 & 3151 & $\begin{array}{l}3164 \\
1699\end{array}$ \\
\hline $\begin{array}{l}\text { Log likelihood } \\
\text { LR test for random } \\
\text { effects }\end{array}$ & -3567.0 & -3557.6 & -3554.5 & $\begin{array}{l}-3546.6 \\
15.75^{* * *}\end{array}$ & -1544.9 & -1539.0 & $\begin{array}{l}-1534.2 \\
9.67 * * *\end{array}$ \\
\hline
\end{tabular}

Robust standard errors in parentheses

* significant at $10 \% ; * *$ significant at $5 \% ; * * *$ significant at $1 \%$

Duration dummies not shown. We also control for industry effects (2-digit SIC 1995),

regional effects (NUTS 3) and cohort effects.

\subsection{Export exit}

The second part of the analysis concentrates on the factors explaining export market exit. Descriptive analysis (Figures 4 and 5) shows that approximately 25 percent of plants that start exporting exit already after the first year. The decline in the cumulative proportion of survivors becomes more modest after approximately the first 5 years in the export market, which may be seen as the most critical period for new exporters. In contrast to export entry, there is not much difference between foreign-owned and domestic plants in the cumulative probabilities of exiting the export market when other factors are not accounted for.

The estimates for the export exit models are presented in Table 4. Many of the effects are consistent with the results on entry. For example, plant size has a negative impact on exit, whereas it was positively related to entry. Probability of exit increases with plant age, but when age group variables are used the impact is not significant in the oldest age groups. It seems that especially young plants that have accumulated less learning are vulnerable in 
export markets. Also the impacts of productivity, capital intensity, and foreign ownership are symmetric to the entry results, since these variables increase the probability of entry and decrease that of exit.

Figure 6 shows clearly the differences between the effects of foreign ownership for small and larger plants. In fact, for small plants with 50 employees or less foreign ownership increases the risk of export exit, whereas for larger plants the risk of failure decreases. This may reflect the higher likelihood of being shut down for small plants acquired by foreign firms. Other interactions of foreign ownership turn out to be statistically insignificant except for labour productivity (results not reported in the table). In this case, the effect of foreign ownership turns positive and its interaction with labour productivity is negative. Thus, foreign ownership increases the risk of failure less for plants with higher efficiency. In fact, for plants with the highest productivity the risk of failure decreases.

In contrast to the entry models, profitability has a significant effect. Profitable plants are less likely to exit, as expected. Plants belonging to multi-unit firms are more likely to exit. More precisely, the hazard for a multi-unit plant is $\exp (0.287)=1.33$ times the hazard for a singleunit plant (according to model 3). This can partly be explained by their better possibilities of shifting export production from one plant to another. Furthermore, the chances of shutting down a plant completely are higher in a multi-unit firm than a single-unit firm.

The employment share of other exporters in the same industry has a negative effect on export exit. However, this effect disappears when more detailed (3-digit SIC 1995) industry dummies are included in the estimation (other effects do not change). Regional spillovers do not turn out to be statistically significant (not reported). Thus, in the exit phase, the role of other firms as competitors seems to outweigh the positive spillover effects.

Among the employee characteristics the results are somewhat different from the entry models. Higher average employee age increases exit probability. This corresponds to the effects of plant age. Somewhat surprisingly, plants with a high share of employees with technical education are more likely to exit from the export market. However, this may reflect the higher overall proportion of exporters in high-technology industries. A high share of employees with 
technical education may also indicate too little emphasis on marketing, which can have a negative impact on survival in the export market.

Again, random effects estimation does not change the results much even though the likelihood ratio test rejects the null hypothesis of no plant-level unobserved effects.

Table 4. Estimation results for export market exit

\begin{tabular}{|c|c|c|c|c|c|c|}
\hline EXIT & $(1)$ & $(2)$ & (3) & (4) & $(5)$ & (6) \\
\hline Plant size & $\begin{array}{l}-0.690 \\
(0.047) * * *\end{array}$ & $\begin{array}{l}-0.665 \\
(0.046) * * *\end{array}$ & $\begin{array}{l}-0.709 \\
(0.050) * * *\end{array}$ & $\begin{array}{l}-0.783 \\
(0.056) * * *\end{array}$ & $\begin{array}{l}-0.707 \\
(0.079) * * *\end{array}$ & $\begin{array}{l}-0.784 \\
(0.075)^{* * *}\end{array}$ \\
\hline Plant age & $\begin{array}{l}0.007 \\
(0.002)^{* * *}\end{array}$ & & & & & \\
\hline Plant age group 2 & & $\begin{array}{l}-0.020 \\
(0.100)\end{array}$ & $\begin{array}{l}-0.028 \\
(0.100)\end{array}$ & $\begin{array}{l}-0.047 \\
(0.115)\end{array}$ & $\begin{array}{l}-0.003 \\
(0.178)\end{array}$ & $\begin{array}{l}-0.003 \\
(0.203)\end{array}$ \\
\hline Plant age group 3 & & $\begin{array}{l}-0.115 \\
(0.093)\end{array}$ & $\begin{array}{l}-0.118 \\
(0.092)\end{array}$ & $\begin{array}{l}-0.144 \\
(0.106)\end{array}$ & $\begin{array}{l}-0.048 \\
(0.163)\end{array}$ & $\begin{array}{l}-0.020 \\
(0.185)\end{array}$ \\
\hline Plant age group 4 & & $\begin{array}{l}-0.207 \\
(0.092)^{* *}\end{array}$ & $\begin{array}{l}-0.211 \\
(0.092)^{* *}\end{array}$ & $\begin{array}{l}-0.266 \\
(0.107)^{* *}\end{array}$ & $\begin{array}{l}-0.293 \\
(0.157)^{*}\end{array}$ & $\begin{array}{l}-0.348 \\
(0.179) *\end{array}$ \\
\hline $\begin{array}{l}\text { Plant age group } 5 \\
\text { (the youngest) }\end{array}$ & & $\begin{array}{l}-0.274 \\
(0.108)^{* *}\end{array}$ & $\begin{array}{l}-0.283 \\
(0.109) * * *\end{array}$ & $\begin{array}{l}-0.347 \\
(0.123) * * *\end{array}$ & $\begin{array}{l}-0.389 \\
(0.160)^{* *}\end{array}$ & $\begin{array}{l}-0.457 \\
(0.179)^{* *}\end{array}$ \\
\hline Labour productivity & $\begin{array}{l}-0.265 \\
(0.049) * * *\end{array}$ & $\begin{array}{l}-0.267 \\
(0.048) * * *\end{array}$ & $\begin{array}{l}-0.264 \\
(0.048) * * *\end{array}$ & $\begin{array}{l}-0.269 \\
(0.052) * * *\end{array}$ & $\begin{array}{l}-0.259 \\
(0.094) * * *\end{array}$ & $\begin{array}{l}-0.258 \\
(0.100)^{* * *}\end{array}$ \\
\hline Capital intensity & $\begin{array}{l}-0.096 \\
(0.020)^{* * *}\end{array}$ & $\begin{array}{l}-0.097 \\
(0.020)^{* * *}\end{array}$ & $\begin{array}{l}-0.096 \\
(0.020)^{* * *}\end{array}$ & $\begin{array}{l}-0.106 \\
(0.022)^{* * *}\end{array}$ & $\begin{array}{l}-0.093 \\
(0.031)^{* * *}\end{array}$ & $\begin{array}{l}-0.107 \\
(0.033)^{* * *}\end{array}$ \\
\hline Investment rate & $\begin{array}{l}-0.275 \\
(0.187)\end{array}$ & $\begin{array}{l}-0.275 \\
(0.188)\end{array}$ & $\begin{array}{l}-0.276 \\
(0.188)\end{array}$ & $\begin{array}{l}-0.251 \\
(0.169)\end{array}$ & $\begin{array}{l}-0.841 \\
(0.497)^{*}\end{array}$ & $\begin{array}{l}-0.762 \\
(0.406)^{*}\end{array}$ \\
\hline Price-cost margin & $\begin{array}{l}-0.355 \\
(0.188)^{*}\end{array}$ & $\begin{array}{l}-0.365 \\
(0.182)^{* *}\end{array}$ & $\begin{array}{l}-0.376 \\
(0.182)^{* *}\end{array}$ & $\begin{array}{l}-0.382 \\
(0.180) * *\end{array}$ & $\begin{array}{l}-0.276 \\
(0.384)\end{array}$ & $\begin{array}{l}-0.295 \\
(0.390)\end{array}$ \\
\hline Multi-unit & $\begin{array}{l}0.253 \\
(0.058) * * *\end{array}$ & $\begin{array}{l}0.274 \\
(0.059) * * *\end{array}$ & $\begin{array}{l}0.287 \\
(0.059) * * *\end{array}$ & $\begin{array}{l}0.307 \\
(0.066) * * *\end{array}$ & $\begin{array}{l}0.341 \\
(0.088) * * *\end{array}$ & $\begin{array}{l}0.368 \\
(0.099)^{* * *}\end{array}$ \\
\hline Foreign ownership & $\begin{array}{l}0.131 \\
(0.094)\end{array}$ & $\begin{array}{l}0.134 \\
(0.094)\end{array}$ & $\begin{array}{l}-1.301 \\
(0.494) * * *\end{array}$ & $\begin{array}{l}-1.324 \\
(0.494) * * *\end{array}$ & $\begin{array}{l}-1.412 \\
(0.744)^{*}\end{array}$ & $\begin{array}{l}-1.506 \\
(0.722)^{* *}\end{array}$ \\
\hline $\begin{array}{l}\text { Foreign ownership* } \\
\text { plant size }\end{array}$ & & & $\begin{array}{l}0.362 \\
(0.120)^{* * *}\end{array}$ & $\begin{array}{l}0.365 \\
(0.119) * * *\end{array}$ & $\begin{array}{l}0.323 \\
(0.185)^{*}\end{array}$ & $\begin{array}{l}0.336 \\
(0.177)^{*}\end{array}$ \\
\hline Share of other exporters & $\begin{array}{l}-0.455 \\
(0.178)^{* *}\end{array}$ & $\begin{array}{l}-0.463 \\
(0.179)^{* * *}\end{array}$ & $\begin{array}{l}-0.485 \\
(0.177)^{* * *}\end{array}$ & $\begin{array}{l}-0.530 \\
(0.200) * * *\end{array}$ & $\begin{array}{l}-0.799 \\
(0.285) * * *\end{array}$ & $\begin{array}{l}-0.845 \\
(0.311)^{* * *}\end{array}$ \\
\hline Mean age of employees & & & & & $\begin{array}{l}0.037 \\
(0.014) * * *\end{array}$ & $\begin{array}{l}0.039 \\
(0.013)^{* * *}\end{array}$ \\
\hline Mean seniority & & & & & $\begin{array}{l}-0.000 \\
(0.001)\end{array}$ & $\begin{array}{l}-0.000 \\
(0.001)\end{array}$ \\
\hline $\begin{array}{l}\text { Share of technically } \\
\text { educated }\end{array}$ & & & & & $\begin{array}{l}0.570 \\
(0.279)^{* *}\end{array}$ & $\begin{array}{l}0.659 \\
(0.289)^{* *}\end{array}$ \\
\hline Share of highly educated & & & & & $\begin{array}{l}-0.024 \\
(0.234)\end{array}$ & $\begin{array}{l}-0.066 \\
(0.241)\end{array}$ \\
\hline Share of women & & & & & $\begin{array}{l}0.167 \\
(0.252)\end{array}$ & $\begin{array}{l}0.217 \\
(0.268)\end{array}$ \\
\hline Growth in real GDP & $\begin{array}{l}-1.380 \\
(0.929)\end{array}$ & $\begin{array}{l}-1.383 \\
(0.930)\end{array}$ & $\begin{array}{l}-1.367 \\
(0.931)\end{array}$ & $\begin{array}{l}-1.447 \\
(0.918)\end{array}$ & $\begin{array}{l}0.772 \\
(1.446)\end{array}$ & $\begin{array}{l}0.777 \\
(1.426)\end{array}$ \\
\hline Constant & $\begin{array}{l}2.424 \\
(0.257) * * *\end{array}$ & $\begin{array}{l}2.465 \\
(0.268) * * *\end{array}$ & $\begin{array}{l}2.629 \\
(0.274) * * *\end{array}$ & $\begin{array}{l}2.851 \\
(0.295) * * *\end{array}$ & $\begin{array}{l}1.141 \\
(0.669) *\end{array}$ & $\begin{array}{l}1.154 \\
(0.691)^{*}\end{array}$ \\
\hline Random effects & NO & NO & NO & YES & NO & YES \\
\hline Observations & 15197 & 15198 & 15198 & 15318 & 6490 & 6490 \\
\hline
\end{tabular}


Number of id

Log likelihood

$-5198.6$

2911

1588

LR test for random

$-5200.9$

$-5196.0$

$-5195.0$

$-2286.6$

$-2283.7$

effects

Robust standard errors in parentheses

* significant at 10\%; ** significant at 5\%; *** significant at $1 \%$

Duration dummies not shown. We also control for industry effects (2-digit SIC 1995),

regional effects (NUTS 3) and cohort effects.

\subsection{Sensitivity analysis}

We have performed several sensitivity analyses of the results in addition to those mentioned above. We report on them briefly without showing the results in tables.

The size threshold of 20 employees causes some concern over the coverage and representativeness of the data. However, the distribution of exporters is heavily concentrated on the larger size categories. According to the Business Register, only around 10 per cent of plants with less than 20 employees are exporters. In order to control for possible previous exports with less than 20 employees, we have excluded from the data those plants that have had exports in two years prior to "birth" (or exceeding the size threshold for the first time). This is only possible for cohorts 1980-1995 for export market entry, which results in a serious drop in the number of observations. Results for export entry are otherwise similar to those presented, but foreign ownership is no longer significant. For export exit, the problem of earlier export experience is not likely to be as severe.

Due to the high share of plants that enter or exit the export market during the first year, we have also tried excluding the one-year observations (with duration=1) from the estimations. As a consequence, foreign ownership is no longer significant in export entry, but otherwise the results remain similar. Instead of allowing for only one-year absences from the data, we have tested the effect of accepting also two-year absences on the results. However, the results remain practically the same as those presented above.

To reduce possible simultaneity problems, we have also tested using lagged values of foreign ownership and labour productivity as explanatory variables. The one-year lagged variables turn out to be statistically insignificant in the entry estimations, whereas for export exit they 
correspond to the previous results. To summarise, the results for the exit model may be considered to be more robust than for export entry.

The advantage of using the plant-level information is that changes in ownership structure do not affect the plant code. In addition, rich set of information is available at the plant level for a lengthy period of time. The plant-level results can be generalised to the firm level with some caution. The share (of employment) of multi-unit firms in the data is around $9 \%$ (54\%) until 1994 and around $15 \%$ (62\%) after 1994. The shifts in production within multi-unit firms may cause some distortion in the plant-level results. However, unfortunately corresponding firmlevel data on export behaviour is not readily available.

\section{Conclusions}

This paper has analysed export market entry and exit from a long-run, dynamic perspective by modelling the duration until exporting and duration until exit from the export market. We have been able to use a rich linked employer-employee data set. Our empirical findings indicate that there is a significant amount of symmetry in the factors affecting export entry and exit in Finnish manufacturing. Larger, younger, more productive and capital-intensive plants are more likely to enter and less likely to exit the export market. Foreign ownership increases the chances of export market entry especially for small plants and plants with less-educated work force. When it comes to export exit, foreign ownership decreases the risk of failure especially for large and more productive plants.

However, especially human capital has diverse effects on export market entry and exit. Entering plants have more educated but less experienced staff, whereas exiting plants have older and more technically-educated staff. The negative impact of technical education on survival in the export market is interesting, as it can be interpreted to be a sign of too little emphasis on marketing.

Another asymmetry in export entry and exit is in the role of industry spillovers from other exporters. In the entry stage plants seem to gain from the experience of others who are already exporting. However, these spillovers have less role in the survival of exporters. 


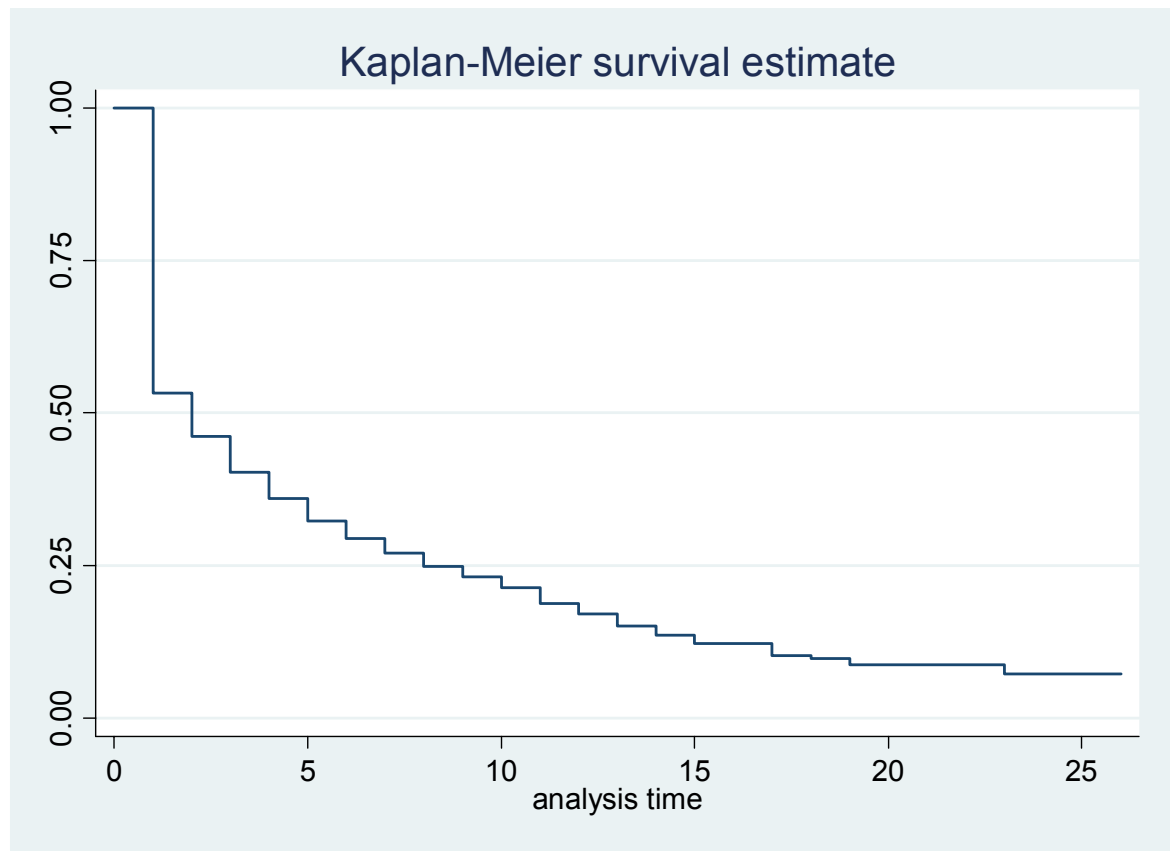

Figure 1: Survival function for export entry

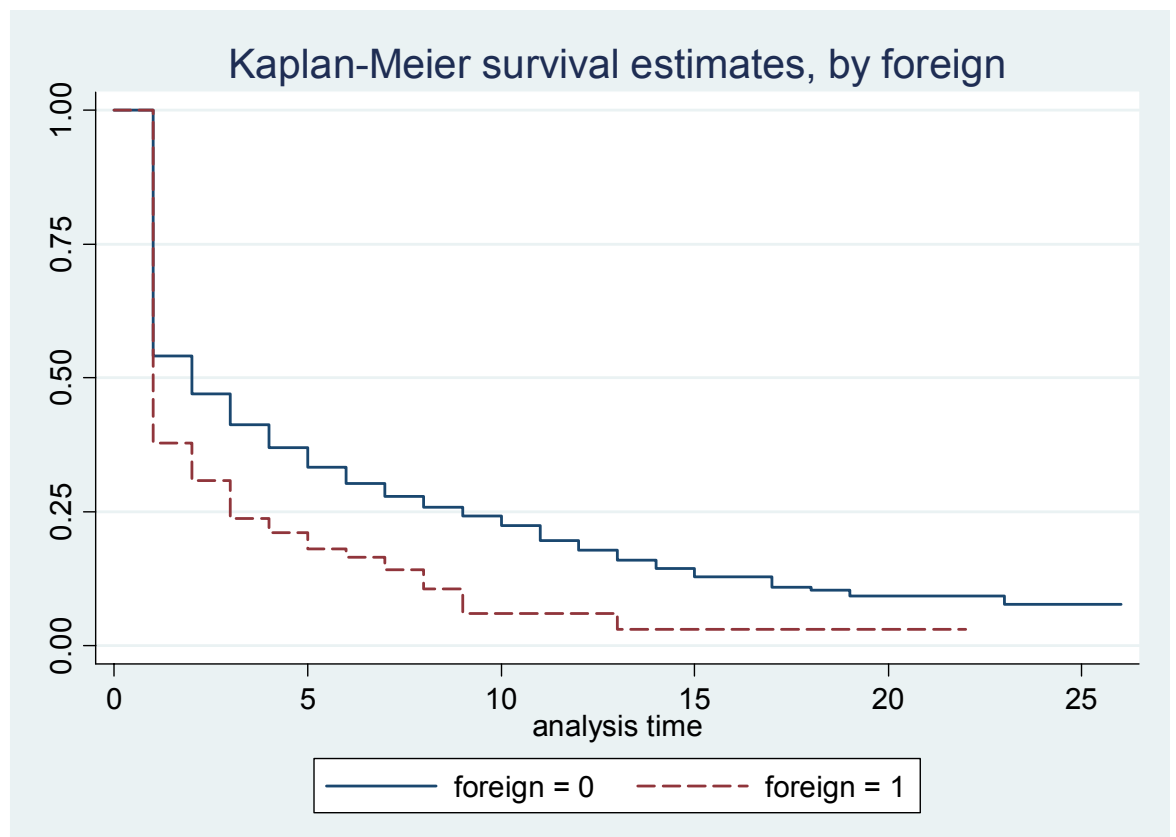

Figure 2: Survival function for export entry by foreign ownership 


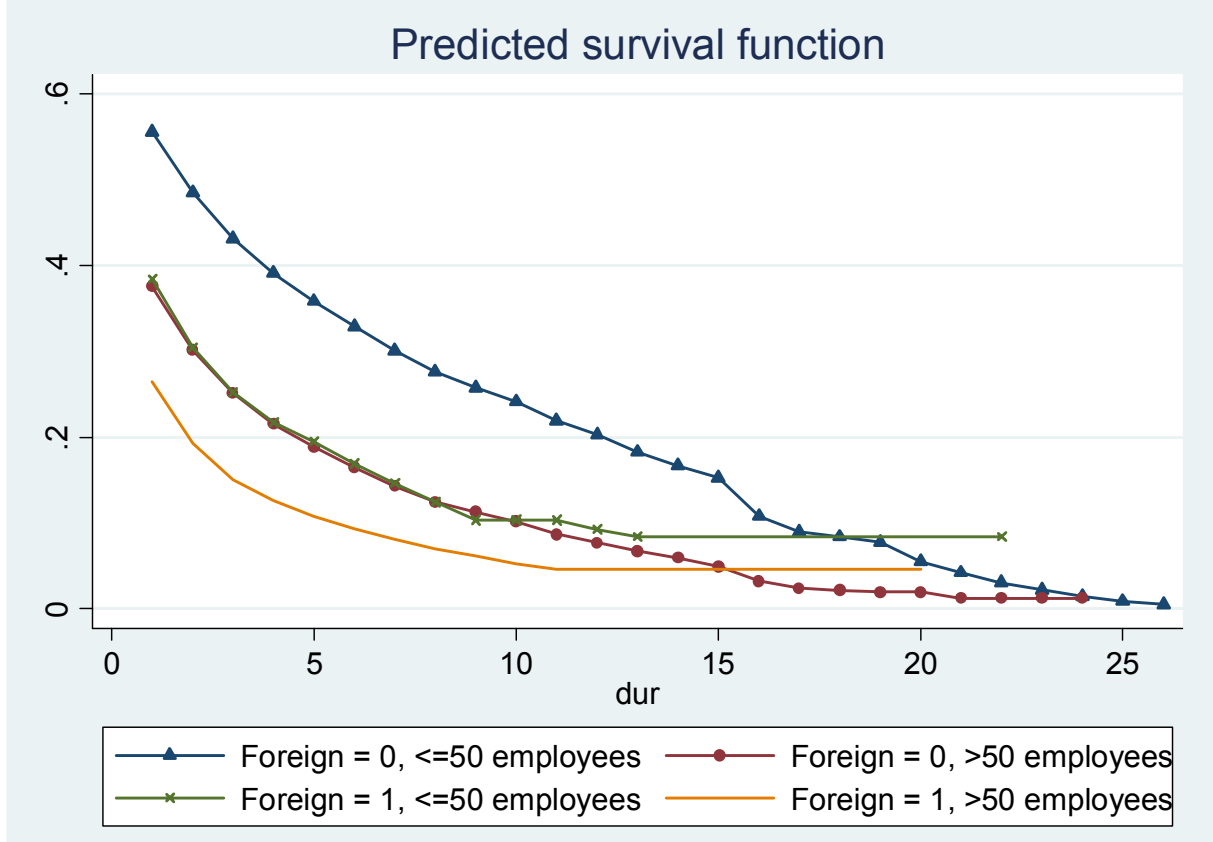

Figure 3: Predicted survival function for export entry by foreign ownership and plant size (based on model 3 in Table 3)

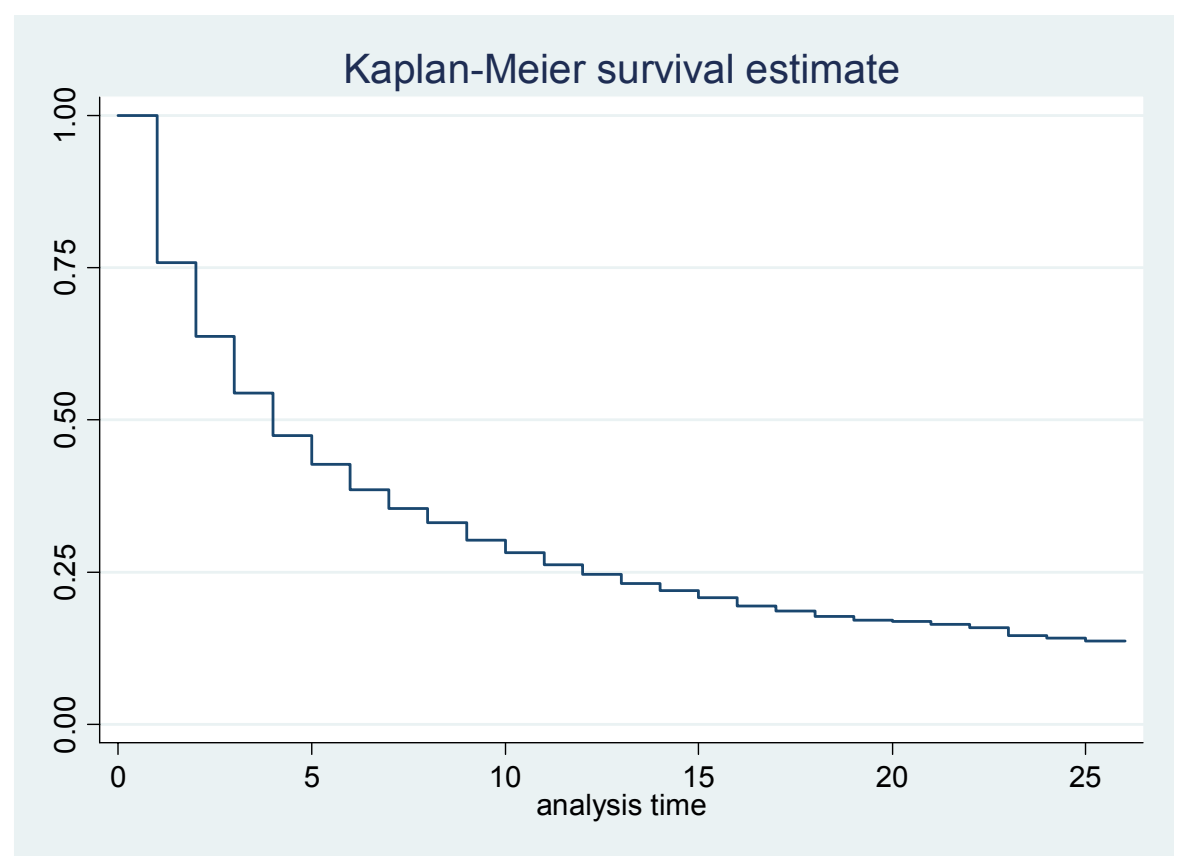

Figure 4: Survival function for export exit 


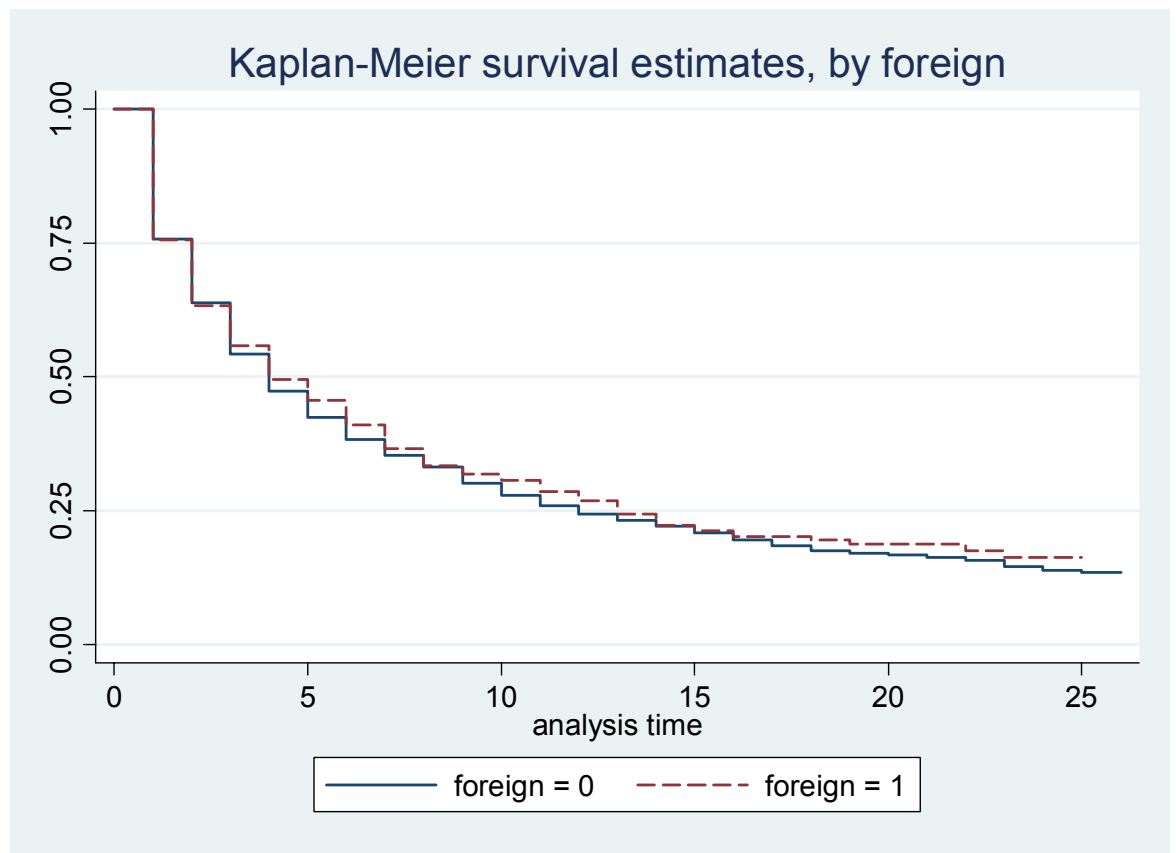

Figure 5: Survival function for export exit by foreign ownership

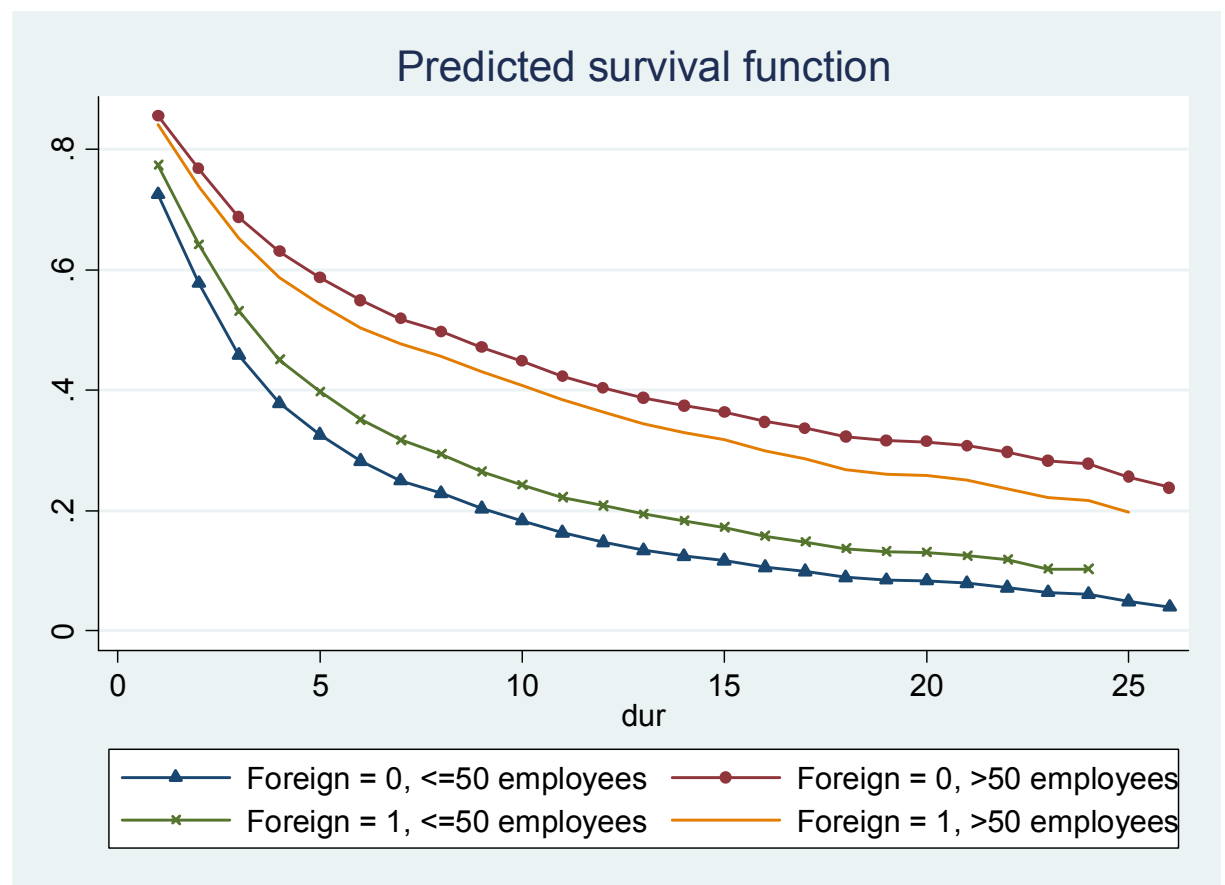

Figure 6: Predicted survival function for export exit by foreign ownership and plant size (based on model 3 in Table 4) 


\section{References}

Alvarez, R. and Lopez, R. A., 2005, 'Exporting and performance: evidence from Chilean plants', Canadian Journal of Economics 38, 1384-1400.

Basile, R., 2001, 'Export behaviour of Italian manufacturing firms over the nineties: the role of innovation', Research Policy 30, 1185-1201.

Bernard, A.B., Eaton J., Jensen J.B., and Kortum, S., 2003, 'Plants and productivity in international trade', American Economic Review 93, 1268-1290.

Bernard, A., \& Jensen, B., 1999, 'Exceptional exporter performance: cause, effect, or both?' Journal of International Economics 47, 1-25.

Bernard, A. B., and Jensen, J. B., 2004, 'Why some firms export?', Review of Economics and Statistics 86, 561-569.

Bernard, A., Redding, S., and Schott, P. (2004). Comparative advantage and heterogeneous firms. Cambridge, Massachusetts: NBER Discussion Paper No. 10668.

Campa, J. M., 2004, 'Exchange rates and hysteresis: How important is hysteresis in trade?', European Economic Review 48, 527-548.

Clerides, S. K., Lach, S., and Tybout, J. R., 1998, 'Is learning by exporting important? Microdynamic evidence from Colombia, Mexico, and Morocco', Quarterly Journal of Economics 113, 903-947.

Das, S., Roberts, M. J., and Tybout, J. R., 2007, 'Market entry costs, producer heterogeneity, and export dynamics', Econometrica 75, 837-873.

Fafchamps, M., Zeufack, A., \& El Hamine, S., 2007, Learning to export: Evidence from Moroccan manufacturing, Journal of African Economies, forthcoming.

Girma, S., Greenaway, D., and Kneller, R., 2003, 'Export market exit and performance dynamics: A causality analysis of matched firms', Economics Letters 80, 181-187.

Girma, S., Greenaway, D., and Kneller, R., 2004, 'Does exporting lead to better performance? A microeconometric analysis of matched firms', Review of International Economics $12,855-866$.

Greenaway, D., \& Kneller, R. (2004). Industry differences in the effect of export market entry: Learning by exporting?: University of Nottingham Working Paper No. 2004/33.

Greenaway, D., and Kneller, R., 2007, 'Firm heterogeneity, exporting, and foreign direct investment', Economic Journal 117, F134-F161. 
Lopez, R. A., 2005, 'Trade and growth: Reconciling the macroeconomic and microeconomic evidence', Journal of Economic Surveys 19, 623-648.

Melitz, M. J., 2003, 'The impact of trade on intra-industry reallocations and aggregate Industry productivity', Econometrica 71, 1695-1725.

Prentice, R., and Gloeckler, L., 1978, 'Regression analysis of grouped survival data with application to breast cancer data', Biometrics 34, 57-67.

Roberts, M. J., \& Tybout, J. R., 1997, 'The decision to export in Colombia: An empirical model of entry with sunk costs', American Economic Review 87, 545-565.

Roper, S., \& Love, J. H., 2002, 'Innovation and export performance: evidence from the UK and German manufacturing plants', Research Policy 31, 1087-1102.

Roper, S., Love, J. H., \& Dolores, A. H., 2006, 'The determinants of export performance: Evidence for manufacturing plants in Ireland and Northern Ireland', Scottish Journal of Political Economy 53, 586-615.

Tybout, J. R., 2003, 'Plant- and firm-level evidence on "new" trade theories', in E. K. Choi and J. Harrigan, eds., Handbook of International Trade, Oxford: Basil Blackwell.

Van Biesebroeck, J., 2005, 'Exporting raises productivity in sub-Saharan African manufacturing firms, Journal of International Economics 67, 373-391.

Wagner, J., 1995, 'Exports, firm size and firm dynamics', Small Business Economics 7, 29-39.

Wagner, J., 2007, 'Exports and productivity: A survey of the evidence', The World Economy $30,60-82$. 